\title{
TindaKan Afirmatif Sebagai Bentuk Keadilan Pada \\ PENEGAKan HuKum LINGKUNGan Hidup di LAUT : Studi Kasus MV Hai Fa dan Nelayan Ujung Kulon
}

\author{
Rayhan Dudayev ${ }^{1}$
}

\begin{abstract}
Abstrak
Upaya penegakan hukum yang tegas merupakan salah satu cara untuk menjaga kelestarian lingkungan. Instrumen hukum lingkungan dibuat dan ditegakkan untuk mencegah terjadinya kerusakan lingkungan. Namun pada pelaksanaannya, penegakan hukum lingkungan tidak senada dengan konsep pembangunan berkelanjutan. Penegakan hukum lingkungan seolah hanya tajam ke bawah namun tumpul ke atas. Dalam tulisan ini, akan dibahas mengenai penegakan hukum lingkungan di sektor maritim dalam dua kasus yang berbeda, berkaitan dengan pelanggaran Undang-Undang Konservasi Nomor 5 Tahun 1990 Tentang Koservasi Sumber Daya Alam dan Ekosistemnya. Perbedaan sebab akibat dalam kasus yang berbeda tidak membuat hukum memperlakukan kedua kasus tersebut secara berbeda karena adanya asas kesamaan (equality before the law) dalam hukum. Tulisan ini akan memaparkan penegakan hukum, terutama hukum pidana, ditinjau dengan perspektif pembangunan berkelanjutan pada kasus nelayan dan kasus illegal fishing yang melibatkan korporasi. Berangkat dari perspektif tersebut, tulisan ini mencoba menganalisis alasan pentingnya tindakan afirmatif bagi penegakan hukum di masing-masing kasus.

Kata Kunci: pembangunan berkelanjutan, penegakan hukum lingkungan, tindakan afirmatif

1 Penulis adalah peneliti di Indonesian Center for Environmental Law (ICEL), mendapatkan gelar Sarjana Hukum dari Fakultas Hukum Universitas Indonesia.
\end{abstract}




\begin{abstract}
One of the means to protect the environment is to firmly enforce the environmental law. Environmental legal instruments are made and enforced in order to prevent environmental damage. However, environmental law enforcement in practice is not always consistent with the concept of sustainable development. Environmental enforcement is sharper to the poor people, but dull to big corporations. This article attempts to discuss the enforcement of environmental law in the maritime sector in two different cases, with regard to the violation of Law no. 5 of 1990 regarding Conservation. Despite the different causation and magnitude of impacts, the law treats those cases equally due to the equality before the law principle. This article also elaborates the law enforcement, especially criminal law, with the perspective of sustainable development in the case of involving fishermen and the illegal fishing case involving a corporation. From this perspective, this paper analyzes the importance affirmative action for the law enforcement in each case.
\end{abstract}

Key Words: Sustainable Development, Enforcing Environmental Law, Affirmative Action

\title{
1. Pendahuluan
}

Di awal tahun 2015, beberapa media ramai memberitakan aksi massa yang didominasi oleh nelayan di depan Pengadilan Negeri Pandegelang. ${ }^{2}$ Massa meminta keadilan terhadap kasus hukum yang menimpa tiga orang nelayan yang menangkap 3 ekor udang di kawasan Taman Nasional Ujung Kulon (“TNUK"). ${ }^{3}$ Mereka ditangkap oleh polisi air atas pelanggaran larangan menangkap ikan di kawasan konservasi dalam Undang-Undang Nomor 5 tahun 1990. Nelayan tersebut merasa tidak mendapatkan keadilan atas penangkapan yang menimpa mereka karena aksi penangkapan ikan sering dilakukan di kawasan tersebut. Penyidik bergeming dengan pembelaan para nelayan. Siapa yang

2 "Demo, Minta Peradilan 3 Nelayan Adil," Banten Raya, 3 Desember 2014, Sumber : http://bantenraya.com/banten-raya/pandeglang/8477-demo-minta-peradilan-3nelayan -adil diakses pada 7 Juli 2015.

3 "Gelombang Ganas Nelayan Miskin Penangkap 4 Udang Terbebas dari Penjara," Detik.com, 29 Januari 2015 http://news.detik.com/read/2015/01/29/095247/ 2817229/10/gelombang-ganas-nelayan-miskin-penangkap-4-udang-terbebas-dari-penjara, diakses pada14 April 2015. 
melanggar ketentuan hukum, harus diproses secara hukum dalam rangka penegakan hukum secara tegas.

Setelah menjalani pemeriksaan penyidikan dan persidangan, hakim memutuskan para nelayan tersebut bebas dari jeratan hukum. Namun, jaksa masih mengajukan kasasi. Kisah tiga orang nelayan ini menjadi déjà vu bagi kisah penegakan hukum lingkungan yang terkesan hanya tajam ke bawah. Sebelum kasus ini, masih lekat dalam ingatan kasus yang menimpa warga adat Semende Banding Agung di kawasan Taman Nasional Bukit Barisan Selatan (“TNBBS”). ${ }^{4}$

Di lain tempat dan waktu, hipotesis penegakan hukum lingkungan yang tumpul ke atas tercermin dari lemahnya penegakan hukum terhadap pelaku pencurian ikan. Premis tersebut sementara dapat disimpulkan melalui kasus MVV Hai Fa. Kapal dengan bobot 4.300 GT itu membawa 900,702 ton ikan yang diduga hasil curian dengan kerugian negara diperkirakan mencapai 70 Miliar rupiah. ${ }^{5}$ Kapal MV Hai Fa yang berbendera Panama ${ }^{6}$ melanggar banyak pasal, di samping kejahatan pencurian ikan, MV Hai Fa juga melakukan kejahatan lingkungan karena melakukan penagkapan satwa dilindungi, yaitu hiu martil dan hiu konoi. Ironisnya, putusan pengadilan hanya menghukum nahkoda dan anak buah kapal ("ABK") dengan pidana penjara selama satu tahun dan denda sebesar 250 juta rupiah. ${ }^{7}$

jaksa hanya menuntut ${ }^{8}$ berdasarkan pelanggaran Pasal 100 jo. Pasal 7 ayat (2) huruf m Undang-Undang Nomor 31 Tahun 2004 tentang Perikanan jo. Undang-Undang Nomor 45 Tahun 2009 (amandemennya, secara kolektif dirujuk sebagai “UU Perikanan”) mengenai kewajiban mematuhi ketentuan jenis ikan yang dilarang untuk diperdagangkan, dimasukkan, dan dikeluarkan ke dan dari wilayah Negara Republik Indonesia serta dua ketentuan lain terkait kepemilikan Surat Layak Operasional (SLO) dan aktivasi alat pemantau kapal penangkap dengan

\footnotetext{
4 "Jadi Tersangka, Empat Warga Adat Semende Banding Agung Dijerat UU P3H," Mongabay, 24 Desember 2013, http://www.mongabay.co.id/2013/12/24/jadi-tersangka-empat-warga-adat-semendebanding-agung-dijerat-uu-p3h/, diakses pada 7 Juli 2015.

5 “Menteri Susi Tegaskan Kapal MV Hai Fa Ilegal," Liputan 6, 13 April 2015, http://bisnis.liputan6.com/read/2212459/menteri-susi-tegaskan-kapal-mv-Hai Failegal, diakses pada 14 April 2015.

$6 \quad$ Pengadilan Negeri Ambon, $\quad$ "Putusan No.
01/PID.SUS/PRK/2015/PN.Amb."
7 Ibid.
8 Ibid.
}


bobot tertentu. Padahal jika melihat ketentuan yang ada, kapal MV Hai Fa telah melanggar beberapa peraturan yaitu: Pasal 16 UU ayat (1) UU Perikanan (larangan ikan hasil tangkapan ke luar wilayah Indonesia), Pasal 29 ayat (1) UU Perikanan (hanya WNI atau badan hukum Indonesia yang dapat melakukan usaha perikanan di Indonesia), Pasal 35A ayat (1) UU Perikanan (nakhoda dan anak buah kapal wajib berkewarganegaraan Indonesia), Pasal 41 ayat (3) UU Perikanan (kewajiban mendaratkan ikan tangkapan di pelabuhan perikanan yang ditetapkan atau pelabuhan lainnya yang ditunjuk), Pasal 41 ayat (4) UU Perikanan (kewajiban melakukan bongkar muat ikan tangkapan di pelabuhan perikanan yang ditetapkan atau pelabuhan lainnya yang ditunjuk) dan Pasal 21 ayat (2) Undang-Undang Nomor 5 Tahun 1990 tentang Konservasi Sumber Daya Alam Hayati dan Ekosistemnya (“UU No. 5 Tahun 1990”) yang melarang menangkap ikan hiu martil dan hiu koboi dengan pidana penjara paling lama 5 tahun dan denda Rp100.000.000,-.

Jaksa menuntut tegas kasus penangkapan ikan di kawasan TNUK. Sementara itu, perbedaan perlakuan jaksa terlihat pada kasus MV Hai Fa dimana jaksa tidak melakukan upaya penuntutan yang progresif. Mengingat banyaknya ketentuan hukum yang dilanggar, seharusnya jaksa dapat melakukan penuntutan lebih berat dengan ganti rugi lebih besar serta perampasan negara berdasarkan Pasal 76A UU Perikanan. Kasus MV Hai Fa dan kasus penangkapan udang oleh nelayan sama dalam hal kedua subyek hukum sama-sama bersalah melanggar hukum. Keduanya diputus dengan putusan pengadilan yang terkesan 'ringan.' Bedanya, kuantitas dan kerugian lingkungan yang ditimbulkan oleh kedua pihak berbeda, yang dalam konteks hukum lingkungan mempunyai pertanggungjawaban hukum yang juga berbeda. ${ }^{9}$ Pertanyaannya, adilkah putusan tersebut jika disandingkan dari perspektif lingkungan? Adilkah jika kedua pelaku diperlakukan sama?

9 Di dalam prinsip pembangunan berkelanjutan terdapat prinsip pembangun yaitu keadilan intera generasi yang di dalamnya juga terdapat prinsip pembangun yaitu keadilan lingkungan sebagai keadilan distributif. Di dalam prinsip tersebut terdapat konsep Common-but-Differential Responsibility (CBDR) yang biasa digunakan untuk membebankan tanggung jawab pada negara-negara yang melakukan pencemaran. Dalam konsep CBDR, tanggung jawab yang dibebankan pada negara maju dan berkembang berbeda karena kontribusi terdahadap pencemaran lingkungan, kemapuan teknologi, dan kondisi keuangan yang berbeda dari masing-masing negara. Lihat: Rio Declaration on Environment and Development, 3-14 Juni 1992, United Nations Treaty Series A/CONF.151/26 (Vol. I), pasal 7; Lihat juga Andri Guna Wibisana, Elemen-Elemen Pembangunan Berkelanjutan-Keadilan Intera dan Antar Generasi, hal. 6. 


\section{Menyoal Equality Before The Law dalam Penegakan Hukum Lingkungan}

Hukum ada karena kekuasaan yang sah. Sebaliknya, kekuasaan yang sah menciptakan hukum. Hukum adalah kekuasaan, yang mengusahakan ketertiban yang diciptakan oleh kekuasaan yang sah. ${ }^{10}$ Walaupun begitu, pengekangan kekuasaan merupakan unsur esensial dan tiada kekuasaan yang kebal terhadap rule of law, yang berarti pengaturan oleh hukum atau lebih dikenal dengan istilah supermasi hukum. ${ }^{11}$ Menurut Albert Venn Dicey, seorang yuris asal Inggris pada abad 19-20, rule of law mengandung tiga unsur, yaitu hak asasi manusia dijamin lewat undang-undang, persamaan di muka hukum (equality before the law), dan supremasi aturan hukum serta tidak ada kesewenangwenangan tanpa aturan yang jelas. ${ }^{12}$ Rule of law ini hadir di dalam Pasal 1 ayat (3) UUD NRI 1945. ${ }^{13}$

Rule of law dalam pelaksanaannya menemui kendala, terutama saat diaplikasikan pada negara bekas jajahan dan di era kapitalisme global. ${ }^{14}$ Hal tersebut berkaitan dengan karakteristik hukum yang merupakan sebuah sistem bebas di dalam ruang yang tertutup. ${ }^{15}$ Karakteristik tersebut diperkuat oleh H.L.Hart, seorang positivis hukum, dalam bukunya yang berjudul A General Concept of Law, menyatakan bahwa teori hukum harus umum dan deskriptif, tidak bergantung pada sistem budaya dan budaya hukum tertentu. ${ }^{16}$ Konsepsi keumuman hukum itu dipertegas dengan pendapat Kelsen yang menyatakan bahwa hukum

10 Sudikno Merto Kusomo, Mengenal Hukum Suatu Pengantar, (Yogyakarta : Liberti, 2007), hal. 25-26.

11 Ibid.

12 Ibid., hal. 28.

13 Pasal tersebut berbunyi "Negara Indonesia adalah Negara Hukum."

14 Dalam penulisannya, Donny menggambarkan pemikiran Brian Z.. Tamanha, profesor hukum di St. John's University School of Law, New York tetang Sosio-legal Positivis yang menyatakan bahwa teori hukum umum tersebut tidak bisa dibangun dari berbagai asumsi lama tentang relasi antara hukum dan masyarakat, terutama anggapan hukum sebagai cerminan perilaku masyarakat. Pada kenyatannya sering kali hukum menjadi tidak efektif karena kehidupan masyarakat lebih diatur oleh norma-norma lainnya. Lihat: Donny Danardo, "Mepertimbangkan Brian Z. Tamanaha: Sosio-Legal Positivis, Anti-Esensialisme, dan Pragmatisme," dalam Sosiologi Hukum dalam Perubahan (Jakarta: Yayasan Obor Indonesia, 2009), hal. 314.

15 Sudikno, op.cit., hal. 201.

16 Donny, op.cit., hal. 314. 
terlepas dari nilai benar dan salah atau keadilan secara absolut, maka hukum adalah pemenuhan kepentingan individu yang setara diformulasikan sebagai kehendak mayoritas. ${ }^{17}$ Itu berarti kaidah hukum, termasuk salah satunya asas equality before the law berlaku bagi siapapun, tidak terkecuali.

Asas kesamaan menghendaki adanya keadilan, dalam arti di dalam hukum setiap orang harus diperlakukan sama (equality before the law). Perkara yang sama (sejenis) harus diputus sama (serupa) pula: similia similibus. ${ }^{18}$ Keadilan diasosiasikan dengan realisasi asas kesamaan tersebut. Frasa itu senada dengan konsepsi justice for all di Amerika Serikat (AS). Penduduk AS yang memiliki sejarah hukum dan tradisi politik yang panjang kerap menyuarakan "justice for all." Sebaliknya, menurut, Prof. Sulistyowati, Bangsa Indonesia masih perlu menyuarakan: "justice for disavantage group," keadilan bagi kelompok yang tidak diuntungkan, termasuk kaum miskin, perempuan dan anak. ${ }^{19}$ Nampaknya, equality before the law perlu dipersoalkan ketika prinsip tersebut menafikan adanya jurang sosial dan ketidaksetaraan di masyarakat, terutama dalam konteks Bangsa Indonesia.

Idealnya, equality before the law dapat berlaku bila setiap orang memiliki akses yang sama terhadap sumber daya dan keadilan. ${ }^{20}$ Menurut logika silogisme hukum dengan penalaran deduktif, ${ }^{21}$ berdasarkan prinsip tersebut, setiap orang yang merambah hutan atau melakukan kegiatan pemanfaatan di kawasan konservasi dapat dipidana tanpa memandang kelas sosial dan aksesibilitasnya. Hukum tidak memikirkan bahwa kemiskinan dan keadaan terpinggirkan timbul karena dampak laten konstruksi politik dan ekonomi yang sebenarnya disahkan oleh kebijakan hukum itu sendiri, ${ }^{22}$ yang menjauhkan orang miskin dari akses keadilan dan sumber daya.

\section{Kasus Nelayan TNUK sebagai Kasus Struktural}

17 Prof. Dr. Jimly Asshiddiqie, S.H. dan Dr. M. Ali Sa'at, S.H., M.H., Teori Hans Kelsen, (Jakarta: Konpress, 2012), hal. 19.

18 Sudikno,op.cit., hal. 46.

19 Sulistyowati Irianto, "Menuju Pembangunan Hukum Pro Keadilan Rakyat," dalam, Sosiologi Hukum dalam Pembangunan (Jakarta: Yayasan Obor Indonesia, 2009), hal. 11.

${ }^{20}$ Ibid., hal. 12.

21 Tan Malaka, Madilog (Materialisme, Dialektika, dan Logika), cet. 4, (Jakarta: LPPM Tan Malaka, 2008), hal. 209-210.

22 Op.cit. 
Robert Merton, seorang sosiolog, mengaitkan masalah kejahatan dengan struktur sosial (strain theory) yang menawarkan tujuan yang sama untuk semua anggotanya (agen sosial) tanpa memberi sarana yang merata untuk mencapainya. ${ }^{23}$ Kekurangpaduan antara apa yang diminta oleh budaya dan kebutuhan dengan apa yang diperbolehkan oleh struktur (yang mencegah memperoleh kebutuhan itu) dapat menyebabkan norma-norma runtuh karena tidak lagi efektif untuk membimbing tingkah laku. ${ }^{24}$ Namun dalam hal ini, Merton hanya mengaitkan masyarakat dalam konteks masyarakat AS yang ia gambarkan beriorientasikan kelas; masing-masing orang didorong untuk mencapai kelas teratas namun dengan sarana yang minim. Ihwal tersebut membuat orang yang dalam tekanan besar akan melakukan kejahatan karena disparitas antara tujuan dan sarana yang tidak seimbang.

Di dalam konteks nelayan Indonesia, ${ }^{25}$ khususnya dalam kasus nelayan TNUK, nelayan mempunyai tujuan yang cukup sederhana yaitu mencari ikan untuk menyambung hidup. Namun, mereka mengalami keterbatasan sarana ${ }^{26}$ dalam mencari ikan seperti alat tangkap yang sangat sederhana serta ketiadaan alat penunjuk arah. ${ }^{27}$ Dengan keterbatasan tersebut, nelayan mencari ikan hingga ke wilayah yang tidak dapat mereka tentukan - berbeda dengan kapal besar yang memiliki GPS. ${ }^{28}$ Dikarenakan batas taman nasional yang tidak jelas, ketiga nelayan tersebut pun menangkap udang dan kepiting yang ternyata berada di kawasan TNUK. Pada saat itu juga, mereka ditangkap oleh petugas TNUK yang sedang berada di lokasi. Para nelayan tersebut dianggap dengan sengaja melakukan pemanfaatan di kawasan TNUK. Padahal, perluasan kawasan TNUK $^{29}$ yang mereduksi zona pemanfaatan

23 Freda Adler, Criminology, (New York: McGraw-Hill, 2001), hal.35 .

24 Topo Santoso dan Eva Achjani Zulfa, Kriminologi, (Jakarta: Rajawali Pers, 2009), hal. 61.

25 Dalam konteks struktural fungsional nelayan merupakan agen sosial yang menjalani fungsi sosial.

${ }^{26}$ Abdul Halim, Bukan Bangsa Kuli, (Jakarta: KIARA, 2014), hal. 39.

27 Kronologis dalam Pengadilan Negeri Pandeglang, "Putusan No. 247/Pid.B/2014/PN.Pdl."

28 Global Positioning System merupakan Alat Pelacak untuk mengetahui posisi keberadaan.

${ }^{29}$ Berdasarkan Keputusan Menteri Kehutanan Republik Indonesia No. SK3658/Menhut-VII/KUH/2014. 
warga tidak ditunjang dengan batas-batas yang jelas dalam perairan taman nasional. ${ }^{30}$

Pisau analisis dari strain theory Robert K. Merthon dalam kajian kriminologi bukan untuk membenarkan perbuatan agen sosial (nelayan) untuk tidak menaati apa yang diperbolehkan oleh struktur. Alat tersebut merupakan alat bantu bagi penegak hukum untuk melihat dengan terang penyebab seseorang melakukan perbuatan yang dilarang oleh struktur (dalam hal ini norma hukum). Teori tersebut mencoba memfasilitasi penegak hukum untuk melihat akar permasalahan dari suatu kejahatan. ${ }^{31}$ Dalam kasus nelayan TNUK tersebut, jika ditelaah, permasalahan bukan semata-mata karena nelayan tersebut ingin mendapatkan tangkapan sebanyak-banyaknya, tetapi minimnya sarana seperti alat pendukung aktivitas melaut dan menangkap, serta ketiadaan komunikasi dan sosialisasi tentang batas taman nasional sehingga membuat ketiga nelayan melanggar ketentuan UU Nomor 5 Tahun 1990.

Sarana merupakan komponen utama dalam rangka penaatan hukum oleh masyarakat atau aktor lain yang dituju oleh suatu aturan hukum. Dalam kasus ini, salah satu sarana yang dibutuhkan oleh nelayan dalam penaatan ialah konsensus pada saat penetapan kawasan taman nasional, bukan lagi sekedar penetapkan aturan yang bersandarkan pada teori fiksi, yang menyatakan bahwa diundangkannya suatu peraturan perundang-undangan oleh instansi yang berwenang mengandaikan semua orang telah mengetahui peraturan tersebut. ${ }^{32}$ Konsensus tersebut penting untuk menemukan alternatif akses terhadap sumber kebutuhan selain di areal taman nasional. Konsensus tersebut dapat tercapai dengan adanya komunikasi yang pro-aktif dalam pembuatan peraturan sebagaimana yang diungkapkan Jurgen Habermas. ${ }^{33}$ Menurutnya, sebagai sebuah sistem nilai dalam suatu masyarakat majemuk, keabsahan (legitimasi) hukum tidak bisa dibuat berdasarkan filsafat moral tertentu. Hukum yang sah hanya bisa dibuat dalam komunikasi inter-subyektif antara negara dan para subyek

30 Mengacu pada Putusan No. 247/Pid.B/2014/PN.Pdl., Op. Cit.

31 Guru Besar Universitas Amsterdam, W.A. Bonger mengatakan bahwa kriminologi merupakan ilmu pengetahuan yang bertujuan menyelidiki gejala kejahatan seluas-luasnya. Lihat: W.A. Bonger, Pengantar Tentang Kriminologi, (Jakarta: PT. Pembangunan Ghalia Indonesia, 1982), hal. 21.

32 Ignotaria iuris neminem excusat yang berarti ketidaktahuan seseorang akan hukum tidak dapat membebaskan orang itu dari tuntutan hukum. Lihat: Maria Farida Indrati S., Ilmu Perundang-Undangan 2, (Jakarta: Kanisius, 2007), hal. 152.

${ }^{33}$ Jurgen Habermas merupakan salah satu tokoh teori kritis dari Jerman. 
hukum. Proses komunikasi dan konsensus yang dicapai dapat menyadari sampai sejauh mana hak-hak subyek hukum. Bagi Habermas, teori komunikasi akan membuat hukum tidak hanya melindungi kepentingan pribadi para subjek hukum, tetapi juga menjamin integrasi sosial. ${ }^{34}$ Pada saat nelayan tidak mengetahui hak-haknya dan pada saat itu melakukan pelanggaran hukum, seyogiyanya tindakan afirmatif ${ }^{35}$ perlindungan lingkungan dengan cara pembuatan kebijakan taman nasional dan penegakan hukum pada nelayan tersebut digunakan.

\section{Keadilan Intra Generasi dalam Pembangunan Berkelanjutan sebagai Pintu Masuk Tindakan Afirmatif dalam Perlindungan Lingkungan}

Konsep pembangunan berkelanjutan ${ }^{36}$ mencoba memberikan tindakan afirmatif bagi masyarakat miskin untuk dapat mengakses sumber daya alam. Konsep tersebut merupakan salah satu prinsip hukum lingkungan. ${ }^{37}$ Prinsip ini identik dengan konsepsi yang

34 Donny, loc.cit., hal. 331.

35 Tindakan Afirmatif yang dimaksud yaitu perlakuan khusus yang diberikan kepada nelayan. Perlakuan khusus tersebut diperlukan supaya posisi nelayan menjadi setara dihadapan hukum. Posisi setara dapat berupa pemberian fasilitas melalui keadilan prosedural yang akan dibahas pada halaman berikutnya untuk mendapatkan informasi, berpartisipasi, dan akses terhadap keadilan dalam pembuatan kebijakan taman nasional sehingga nelayan bukan hanya mengetahui kebijakan tersebut tetapi juga tidak dirugikan dengan dibuat kebijakan tersebut, bahkan diuntungkan. Tindakan afirmatif pada penegakan hukum nelayan yaitu perlakuan khusus yang seharusnya diberikan oleh penegak hukum terhadap nelayan yang 'melanggar hukum' karena keterbatasan sarana yang ia miliki untuk menaati hukum sebagaimana dijelaskan di dalam penedekatan kriminologi di atas. Tindakan afirmatif di sini sebenarnya mengadaptasi apa yang dikemukakan Ratna Kapur, profesor hukum asal India. Kapur menganalogikan pendekatan ini dengan tercapainya keadilan dalam suatu masyarakat apabila kaum cacat memperoleh fasilitas tertentu seperti parkir khusus, toilet khusus supaya mereka dapat melaksanakan fungsinya sebagai anggota masyarakat dengan baik. Perlakuan khusus tersebut bukanlah suatu diskriminasi atau keistimewaan melainkan penghargaan karena keunikan dan perbedaan yang ada. Lihat: Ratna Kapur dan Brenda Cossman, Feminist Engagement with Law in India, (New Delhi: Vedam Books, 1996), hal. 16-19.

${ }^{36}$ Lihat "Rio Declaration on Environment and Development," Op. Cit.

37 Prinsip ini juga tertera di dalam UU 32 Tahun 2009 tentang Perlindungan dan Pengelolaan Lingkungan Hidup salah satunya di dalam pasal 15 ayat (3) huruf c. Lihat: Indonesia, UU Perlindungan dan Pengelolaan Lingkungan 
mengisyaratkan bahwa generasi yang akan datang seminimal mungkin harus bisa menikmati sumber daya alam seperti yang dirasakan oleh generasi yang sekarang. ${ }^{38}$ Berbicara tentang keadilan generasi yang akan datang tidak bisa dilepaskan dari konsep keadilan intra generasi. Bagaimana mungkin membicarakan keadilan yang bersifat futuristik sedangkan keadilan pada saat ini tidak dirasakan. Di dalam prinsip intra generasi, ${ }^{39}$ terdapat empat elemen turunan, salah satunya adalah aspek keadilan lingkungan sebagai keadilan sosial.

Dalam konteks keadilan tersebut, Kuehn menfasirkan keadilan sosial sebagai cabang dari keadilan yang akan mendorong kita untuk melakukan upaya terbaik guna tercapainya tatanan masyarakat yang adil, yaitu tatanan masyarakat yang mampu memenuhi kebutuhan hidup masyarakat. ${ }^{40}$ Keadilan ini juga dapat dilihat dari pandangan yang menyatakan bahwa upaya pengentasan kemiskinan merupakan bagian yang tidak terpisahkan dari upaya perlindungan dan pengelolaan lingkungan. ${ }^{41}$ Tindakan afirmatif di sini ialah perlindungan lingkungan harus dibarengi dengan usaha pengentasan kemiskinan, bukan malah memiskinkan. Kebijakan perlindungan lingkungan melalui kebijakan TNUK yang tidak partisipatif dan minim komunikasi dapat berdampak laten viktimisasi ${ }^{42}$ terhadap nelayan, salah satu bentuknya penangkapan nelayan yang sedang menghidupi diri dan keluarganya. Untuk itu, perlu wadah dalam mewujudkan perlindungan lingkungan yang berkeadilan sosial, di dalam elemen intra generasi berikutnya, yaitu keadilan prosedural.

Keadilan prosedural merupakan keadilan untuk memperoleh perlakuan yang sama. Perlakuan yang sama ini bukanlah persamaan dalam hal distribusi barang dan kesempatan, tetapi persamaan dalam hal mendapatkan perhatian (concern and respect) ketika terjadi pengambilan

Hidup, UU No. 32 Tahun 2009, Lembaran Negara No. 140 Tahun 2009, Tambahan Lembaran Negara No. 5059.

38 M. Jacobs, The Green Economy: Environment, Sustainable Develepoment and the Politics of the Future (Pluto Press, 1991), hal. 79-80 dalam buku Sertifikasi Hakim Lingkungan Hidup (Jakarta: ICEL, 2014), hal. 64.

$39 \mathrm{Ibid}$., hal. 53. Prinsip intra generasi merupakan salah salah satu prinsip turunan pembangunan berkelanjutan.

40 Ibid., hal. 83

${ }^{41}$ Ibid., hal. 84

42 Viktimisasi adalah suatu penimbulan penderitaan (mental, fisik, dan sosial) pada pihak tertentu. Lihat: Arif Gosita, Masalah Korban Kejahatan, (Jakarta: Akademika Presindo, 1993), hal. 139. 
keputusan politik terkait distribusi barang dan kesempatan tersebut. ${ }^{43}$ Keadilan prosedural setidaknya mencakup tiga aspek, yaitu hak untuk berpartisipasi dalam pengambilan keputusan, hak atas informasi, dan akses terhadap keadilan.

Terkait dengan hak untuk berpartisipasi, maka keadilan prosedural dapat dilihat dari apakah pihak yang berpotensi untuk terkena dampak dari sebuah keputusan telah terlibat dalam proses pengambilan keputusan serta menyetujui keputusan yang akan diambil. Dalam hal ini, Kuehn menyatakan bahwa keadilan prosedural tidak sekedar terkait partisipasi di dalam proses pengambilan keputusan, tetapi juga apakah proses pengambilan keputusan tersebut telah dirancang sedemikian rupa sehingga proses ini akan mengarah pada hasil (yaitu distribusi) yang adil. ${ }^{4}$ Dalam konteks ini, maka proses pengambilan keputusan secara deliberatif dianggap sebagai upaya untuk mewujudkan keadilan prosedural, di mana pihak yang lemah (baik secara ekonomi, politik, maupun sosial) diberikan bantuan sumber daya, teknis, dan hukum (tindakan afirmatif) yang akan memungkinkan mereka untuk memperoleh akses yang lebih besar terhadap pengambilan keputusan. ${ }^{45}$ Nelayan di sekitar TNUK ataupun masyarakat miskin pesisir lainnya ${ }^{46}$ perlu mendapatkan perlakuan seperti proses partisipatif dan pengambilan putusan yang deliberatif saat melakukan penetapan kawasan taman nasional di kawasan laut. Saat proses penetapan tidak mengindahkan hal tersebut, besar kemungkinan ketidaktaatan terjadi karena ketidaktahuan atau tidak tersedianya alternatif terhadap akses ekonomi. Penegak hukum perlu menyadari pentingnya proses tersebut supaya dalam melakukan penegakan hukum tidak lagi sekedar menyimpulkan premis umum dan khusus.

Terlepas dari putusan bebas yang diterima oleh ketiga nelayan tersebut, sejak awal tidak seharusnya mereka dibui oleh penyidik. Dengan kewenangan diskresi penyidik, ${ }^{48}$ pihak berwenang tidak harus

43 Andri Gunawan Wibisana, Loc. Cit., hal. 14.

44 Ibid.

45 Ibid., hal. 15.

46 Data Badan Pusat Statistik (BPS) menyebutkan jumlah penduduk miskin di 10.666 desa pesisir tersebar 300 kabupaten/kota dari total 524 kabupaten/kota se-Indonesia mencapai 7,87 juta jiwa atau $25,14 \%$ dari total penduduk miskin nasional yang berjumlah 31,02 juta jiwa. Lihat: Abdul Halim, Loc. Cit., hal. 113.

48 Di dalam pasal 18 UU 2 Tahun 2002 tentang Kepolisian mengindikasikan adanya kewenangan diskresi pada Kepolisian Republik Indonesia (Polri) yaitu: untuk kepentingan umum pejabat Kepolisian Negara Republik Indonesia dalam melaksanakan tugas dan wewenangnya dapat 
memproses perkara dan dengan demikian terikat untuk menunggu putusan pengadilan,49 melainkan dapat menyelesaikan masalah ini dengan alternatif penyelesaian non-hukum dan membebaskan mereka sejak awal. Terlepas perspektif yuridis dari hasil prosesi peradilan, yang memaparkan bahwa para nelayan tidak terbukti melakukan perbuatan yang dapat merusak ekosistem,51 penetapan kawasan taman nasional yang mengacuhkan kepentingan masyarakat secara ekonomi, politik, dan sosial tidak tepat untuk menjadi dasar menghukum para nelayan jika mengacu pada elemen yang ada di prinsip intra generasi. Selain itu, jika melihat kembali dari tinjauan yuridis, dakwaan dari jaksa yang mengacu Pasal 33 ayat (3) jo. Pasal 24 Peraturan Pemerintah No. 28 Tahun 2011 tentang Pengelolaan Kawasan Suaka Alam dan Kawasan Pelestarian Alam ("PP No. 28 Tahun 2011") tidak terpenuhi unsur-unsurnya. Akibat yang disangkakan kepada para nelayan ternyata tidak membahayakan lingkungan serta unsur "kegiatan yang tidak sesuai dengan fungsi zona pemanfaatan dan zona lain dari taman nasional" tidak terpenuhi karena tidak ada pembatasan yang jelas dalam perairan di TNUK. ${ }^{52}$ Hakim membebaskan para nelayan namun jaksa tetap bersikukuh dengan dakwaannya dan terus melakukan upaya hukum ${ }^{53}$ kasasi untuk memidanakan para nelayan.

Berbanding terbalik dengan upaya jaksa yang cukup 'tegas' dalam kasus penangkapan udang, kasus MV Hai Fa yang melibatkan kapal penangkap ikan berkapasitas besar, jaksa memberikan dakwaan yang

bertindak menurut penilaiannya sendiri. Pasal tersebut menunjukan bahwa polisi punya kewenangan untuk melakukan diskresi selama tidak bertentangan dengan etika profesi. Gayus Lumbun mengaitkan diskresi di Kepolisian dengan tiga asas hukum yakni kepastian hukum, keadilan, dan kemanfaatan. Menurut Gayus, anggota Polri di lapangan seringkali berada di posisi dilematis antara menegakkan asas kepastian hukum, kemanfaatan atau keadilan. Solusi atas situasi dilematis ini adalah diskresi. Lihat: "Diskresi Polisi Harus Dibatasi," Hukum Online, 19 September 2012, Sumber: http://www.hukumonline.com/berita/baca/lt5059b7d1c3d3c/ kabareskrim--diskresi-polisiharus-dibatasi

49 "3 Nelayan Terancam 5 Tahun Bui karena Dituduh Curi Kepiting," Merdeka.com, 24 November 2014, Sumber: http://www.merdeka.com/peristiwa/3nelayan-terancam-5-tahun-bui-karena-dituduh-curi-kepiting.html diakses pada 29 April 2015.

51 Rumusan Pasal 33 ayat (3) UU Konservasi No. 5 Tahun 1990. Lihat: Indonesia, Undang-undang Konservasi, UU No. 5 Tahun 1990, Lembaran Negara No. 49 Tahun 1990, Tambahan Lembaran Negara No. 2823.

52 Pertimbangan mejelis hakim dalam pertimbangan Putusan No. 247/Pid.B/2014/PN.Pdl, Op. Cit. Mei 2015.

53 Wawancara tertulis dengan Hendra, Pengacara LBH Jakarta, Jakarta, 29 
cukup ringan. Hakim pun mengamini keringanan yang diajukan jaksa dengan memberikan putusan yang juga ringan. Jika disandingkan dalam tinjauan yuridis dengan pisau analisis keadilan distributif, ${ }^{4}$ kasus MV Hai Fa tidak seimbang dengan kasus nelayan TNUK dari sisi putusan dan dakwaan jaksa.

Keadilan distributif memiliki kaitan yang sangat erat dengan pembangunan berkelanjutan karena tiga alasan, yaitu: pertama, lingkungan hidup merupakan sumber daya yang harus didistribusikan secara adil; kedua, keadilan bersifat fungsional bagi terciptanya keberlanjutan; dan ketiga, keberlanjutan juga membutuhkan adanya keadilan bagi lingkungan hidup itu sendiri.56 Keadilan distributif memberikan perhatian pada dampak lingkungan yang terdistribusi secara tidak adil. ${ }^{57}$ Kondisi ketidakadilan lingkungan bisa ditunjukkan dengan merujuk pada pembagian sumber daya alam dan pemanfaatan yang tidak merata, ataupun pada pembagian resiko kerusakan lingkungan yang juga tidak seimbang. ${ }^{58}$ Lebih jauh lagi, ketidakadilan lingkungan dapat terjadi dalam skala global berupa ketidakadilan terhadap negara miskin / berkembang. Misalnya, dalam persoalan lingkungan global seperti pemanasan global, negara berkembang seringkali menjadi pihak yang paling rentan dan paling menderita akibat dari persoalan tersebut, meskipun kontribusinya terhadap persoalan jauh lebih kecil dibandingkan dengan kontribusi negara maju.59 Dampak kerusakan yang disebabkan oleh tiap orang atau negara berbeda, maka tanggung jawab bagi subyek yang memberikan dampak kerusakan yang lebih besar seharusnya lebih besar. Ihwal tersebut terdefinisikan di dalam prinsip hukum yang tertera di dalam Deklarasi Rio ${ }^{60}$ mengenai common but differentiated responsibilities ("CBDR"). ${ }^{61}$

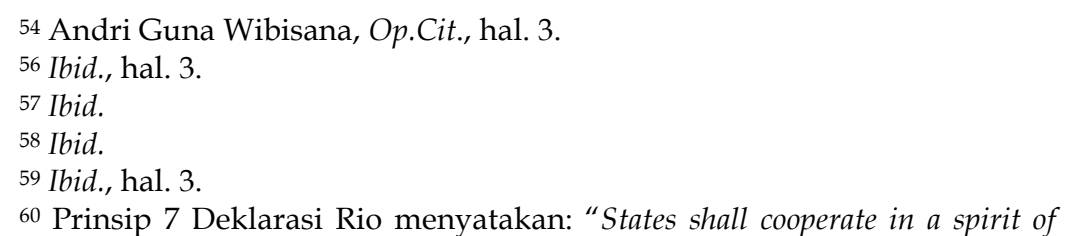
global partnership to conserve, protect and restore the health and integrity of the Earth's ecosystems. In view of the different contributions to global environmental degradation, States have common but differentiated responsibilities. The developed countries acknowledge the responsibility that they bear in the international pursuit of sustainable development in view of the pressures their societies place on the global environment and of the technologies and financial resources they command." Lih: Deklarasi Rio, Op. Cit.

61 Andri G. Wibisana, Loc. Cit. 


\section{Mengaitkan Analisis Yuridis pada Kasus MV Hai Fa dengan Elemen Keadilan Distributif}

Pada kasus MV Hai Fa, jaksa hanya menuntut pidana denda atas pelanggaran terkait sistem pemantauan kapal, standar prosedur operasional, dan membawa ikan yang dilarang untuk diperdagangkan, dimasukan, dan dikeluarkan dari wilayah RI.62 Tuntutan didasarkan fakta bahwa kapal tersebut tidak memilik Surat Layak Operasional (SLO), tidak mengaktifkan alat transmitter yang disebut Vessel Monitoring System (VMS) serta membawa hiu martil dan hiu koboi yang tidak boleh dibawa keluar dari wilayah RI. Padahal, perbuatan yang bertentangan dengan aturan perikanan lebih dari apa yang didakwakan. MV Hai Fa juga tidak memiliki dokumen persetujuan impor barang. Selain itu, ketentuan yang lebih berat yaitu Pasal 88 UU Perikanan serta pasal-pasal lain yang disebutkan di bagian pendahuluan tidak masuk dalam dakwaan jaksa. Terlepas dari tuntutan pidana badan yang perlu ditujukan pada pengurus korporasi pada perusahaan yang mengoperasikan kapal MV Hai Fa, satu hal yang mengecewakan dari tuntutan tersebut yaitu kapal MV Hai Fa tidak dirampas ${ }^{63}$ berdasarkan pasal 76A UU Perikanan agar dapat dimanfaatkan masyarakat Indonesia. Sebagaimana disampaikan Menteri Susi di media massa, ${ }^{64}$ mesin pendingin untuk menyimpan ikan dalam kapal MV Hai Fa merupakan aset yang berharga khususnya bagi nelayan.

Dakwaan yang diajukan jaksa hanya dakwaan alternatif yang menimbulkan konsekuensi masing-masing dakwaan tersebut saling mengecualikan satu sama lain. ${ }^{66}$ Artinya, hakim dapat memilih dakwaan mana yang telah terbukti tanpa memutuskan terlebih dahulu dakwaan lainnya, sekalipun jika dakwaan lain lebih berat. Dalam putusan MV Hai

62 Lihat pasal 100 jo. Pasal 7 ayat (2) huruf d, e, dan m UU 31 Tahun 2004 jo. UU No. 45 Tahun 2009 Tentang Perubahan Atas Undang-Undang No. 31 Tahun 2004, Op. Cit.

63 “Kasus Kapal Maling Ikan Hai Fa Dituntut Ringan," Detik.com, 29 Maret 2015, http://news.detik.com/read/2015/03/29/093954/2872642/10/kasus-kapal-malingikan-hai-fa-dituntut-ringan-penegak-hukum-harus-lebih-jeli, diakses pada 29 April 2015

64 Wiji Nurhayat, "Menteri Susi Ingin Kapal Terbesar dalam Sejarah Ditenggelamkan," Detik.com, 13 Januari 2015, Sumber: http://finance.detik.com/read/2015 /01/13/105047/2801614/4/menteri-susi-ingin-kapalpencuri-ikan-terbesar-dalam-sejarah-ditenggelamkan, diakses pada 8 Juli 2015.

66 Andi Hamzah, Hukum Acara Pidana Indonesia, (Jakarta: Sinar Grafika, 2010), hal. 185. 
Fa, hakim hanya memutuskan bahwa terdakwa terbukti melanggar pasal Pasal 100 jo. Pasal 7 ayat (2) huruf m UU Perikanan. Dalam hal ini, tuntutan jaksa sangat menentukan putusan yang akan dihasilkan hakim jika mengacu pada Pasal 182 ayat (3) dan (4), ${ }^{67}$ walaupun hakim tetap harus memutus berdasarkan keyakinan dan alasan berupa dua alat bukti, sebagaimana tertera di dalam pasal 183 KUHAP.68 Dakwaan kumulatif dan kombinasi untuk menjerat pelaku yang melanggar beberapa ketentuan pidana ${ }^{69}$ tidak digunakan oleh jaksa sehingga subyek yang dihukum hanya nakhoda kapal dan ia hanya dihukum berdasarkan satu pasal saja. Padahal, apabila dicermati, pelanggaran MV Hai Fa masuk dalam kategori concursus realis atau gabungan beberapa kejahatan. ${ }^{70}$ Artinya, nakhoda kapal MV Hai Fa dapat dihukum maksimal 10 (sepuluh) tahun 8 (delapan) bulan berdasarkan Pasal 92 UU Perikanan jika ia dituntut sesuai dengan kuantitas pasal yang dilanggar. ${ }^{71}$

67 Indonesia, Undang-Undang Hukum Acara Pidana, UU No. 8 Tahun 1981, Lembaran Negara No. 76 Tahun 1981. Tambahan Lembaran Negara No. 3209, Lih: Pasal 174 KUHP.

68 Indonesia menganut teori conviction de la raison dalam pembuktian hukum pidana yaitu putusan hakim didasarkan pada keyakinan dan alasan logis. Lih: M. Yahya Harahap, Pembahasan Permasalahan dan Penerapan KUHAP: Pemeriksaan Sidang Pengadilan, Banding, Kasasi, dan Peninjuan Kembali, Edisi 2, cet. 3, (Jakarta: Sinar Grafika, 2002).

69 Jika dicermati perbuatan yang dilanggar oleh subyek di dalam kasus MV Hai Fa ini memenuhi unsur beberapa pasal pada undang-undang yang berbeda yaitu UU Kelautan dan UU Konservasi yang berarti subyek tersebut memenuhi unsur pasal 66 ayat (1) Kitab Undang-Undang Hukum Pidana (KUHP) tentang perbarengan perbuatan yang berbunyi: Dalam hal perbarengan beberapa perbuatan yang masing-masing harus dipandang sebagai perbuatan yang berdiri sendiri-sendiri, sehingga merupakan beberapa kejahatan, yang diancam dengan pidana pokok yang tidak sejenis, maka dijatuhkan pidana atas tiap-tiap kejahatan, tetapi jumlahnya tidak boleh melebihi maksimum pidana yang terberat ditambah sepertiga.

${ }^{70}$ Lihat pasal 66 KUHP.

71 Di dalam pasal 66 tentang concursus realis yang berbunyi: “(1) Dalam hal perbarengan beberapa perbuatan yang masing-masing harus dipandang sebagai perbuatan yang berdiri sendiri sehingga merupakan beberapa kejahatan, yang diancam dengan pidana pokok yang tidak sejenis, maka dijatuhkan pidana atas tiap-tiap kejahatan, tetapi jumlahnya tidak boleh melebihi maksimum pidana yang terberat ditambah sepertiga." Beberapa perbuatan yang dilakukan oleh subyek hukum di dalam kasus MV Hai Fa yang merupakan beberapa perbuatan pidana (seperti tidak memiliki SLO, tidak memasang VMS, menagkap hiu, dll) dapat dikatan concursus realis. Apabila diakumulasikan sanksi pidana dari pasal yang dilanggar, jumlahnya akan melebihi sepuluh (10) tahun, hukuman terberat dari pasal yang dilanggar subyek hukum dalam Mv Hai Fa. Itu berarti, bila mengacu pada pasal ini, pidana penjara maksimal selama 10 tahun dapat 
Hukuman itu, tidak hanya dapat ditujukan kepada nakhoda kapal, tetapi juga pengurus korporasi, termasuk pimpinan perusahaan.

Pasal 101 UU Perikanan menyatakan bahwa pengurus korporasi harus bertanggungjawab terhadap tindak pidana perikanan yang dilakukan oleh korporasi, bahkan pidana denda ditambah sepertiga. Sayangnya, perumusan di dalam undang-undang tersebut belum mengatur secara jelas, siapa subjek dalam korporasi yang dapat dipertanggungjawabkan. Berbeda dengan undang-undang tersebut, Pasal 116 ayat (2) Undang-Undang Nomor 32 tahun 2009 Tentang Perlindungan dan Pengelolaan Lingkungan Hidup (“UU No. 32 Tahun 2009") sudah menggunakan pijakan teori vicarious liability yang memungkinkan korporasi untuk menjadi subjek hukum pidana sehingga sanksi dapat dijatuhkan padanya. ${ }^{72}$ Vicarious liability merupakan ajaran yang berasal dari hukum perdata dalam sistem common law, yaitu doctrine of respondeat superior dimana dalam hubungan karyawan dengan majikan atau antara pemberi kuasa dengan penerima kuasa berlaku adagium "qui facit per alium facit per se" yang berarti seseorang yang berbuat melalui orang lain dianggap sebagai perbuatan yang dilakukan oleh ia sendiri. Dalam hal ini, majikan bertanggung jawab atas kesalahan-kesalahan yang dilakukan oleh karyawannya sepanjang kesalahan tersebut dilakukan dalam rangka pekerjaannya. ${ }^{73}$ Terkait dengan teori ini, will (keinginan) untuk memberantas illegal fishing dapat ditempuh melalui penegakan hukum hingga ke aktor utamanya selain para nelayan dari negara lain ataupun nakhoda kapal, seperti yang terjadi di kasus MV Hai Fa. Sebuah pertanyaan besar perlu dilontarkan ketika kapal yang begitu besar menangkap puluhan ton ikan yang merugikan negara kurang lebih sebesar Rp 70 miliar: apakah tindakan tersebut terencana untuk memperoleh keuntungan bagi korporasi? Dalam kasus pencurian ikan

dijatuhkan, yaitu pasal 92 UU 312004 dengan sanksi terberat yaitu delapan tahun dan ditambah sepertiga, menjadi 10 (sepuluh) tahun 8 (delapan) bulan.

72 Di dalam pasal 116 ayat (1) UU 32 Tahun 2009, badan usaha dapat dijatuhi sanksi pidana. Dalam hal ini pidana penjara dapat dijatuhkan kepada pemberi perintah atau pemimpin kegiatan, tetapi pidana pokok yang dapat dijatuhkan kepada korporasi hanyalah denda. Tetapi, di dalam undang-undang tersebut, korporasi dimungkinkan untuk mendapatkan pidana tambahan berupa penutupan seluruh korporasi dan pembatasan aktivitas korporasi, sehingga korporasi seolah mendapatkan pidana penjara atau kurungan sebagaimana istilah corporate imprisonment. Lih: Raynaldo Sembiring, et.al., Anotasi UndangUndang Nomor 32 Tahun 2009 Tentang Perlindungan dan Pengelolaan Lingkungan Hidup, (Jakarta: ICEL, 2014), hal. 274.

73 Sutan Rehmi Sjahdeini, Pertanggungjawaban Pidana Korporasi, (Jakarta: Grafiti Press, 2006), hlm. 84. 
skala besar, termasuk di dalamnya penangkapan ikan yang dilindungi, penegak hukum tidak boleh lagi menunjukkan perilaku fakultatif untuk menindak tegas mastermind ${ }^{74}$ atau pelaku fungsional dalam sebuah kejahatan korporasi.

Pertanggungjawaban korporasi penting, terutama dalam konteks penegakan hukum lingkungan, apabila melihat beberapa kasus kerusakan lingkungan yang disebabkan oleh aktivitas korporasi. ${ }^{75}$ Meminjam konsep CBDR, seperti halnya negara besar, korporasi yang memiliki kontribusi lebih besar dalam menyebabkan persoalan lingkungan memikul tanggung jawab yang lebih besar untuk mengatasi persoalan lingkungan tersebut. ${ }^{76}$ Konsep CBDR ini dapat digunakan sebagai benang merah dalam membandingkan penegakan hukum lingkungan di laut dalam kasus skala besar (kasus MV Hai Fa) dan kasus struktural (kasus nelayan TNUK) berdasarkan besarnya dampak lingkungan yang ditimbulkan dari masing-masing kasus.

Dalam putusan MV Hai Fa, hal yang memberatkan pelaku hanya sebatas akibat perbuatan yang dapat mengancam kelestarian ikan sebagai sumber daya alam. Hakim tidak mempertimbangkan bahwa kelestarian hiu martil sangat penting untuk menjaga keseimbangan ekosistem laut. ${ }^{77}$ Jika hiu punah, maka tidak akan ada kontrol bagi pertumbuhan-pertumbuhan ikan besar yang memakan ikan-ikan kecil sehingga ikan-ikan kecil itu dapat mengalami ledakan populasi yang juga dapat berujung pada kepunahan. ${ }^{78}$ Punahnya ikan hiu ini akan berdampak pada hasil tangkapan nelayan dan kesejahteraannya. Terlebih, terlepas dari pernyataan yang terkesan antroposentris tersebut, keberadaan hiu ini menjadi penyeimbang keberlanjutan berbagai jenis makhuk hidup, ${ }^{79}$ terutama yang hidup di laut. Berseberangan dengan

74 Yang dimaksud mastermind yaitu pelaku fungsional orang yang memberi perintah atau bertindak sebagai pemimpin dalam tindak pidana. Lih: Raynaldo Sembiring dkk, Op. Cit., hal. 272.

75 Lihat Kasus Lumpur Lapindo.

76 Andri G. Wibisana, Op. Cit., hal. 6.

77 “Moratorium Ekspor Hiu Martil dan Hiu Koboy," Maritime Magazine, 7 Januari 2015, SumberL http://maritimemagz.com/moratorium-ekspor-hiumartil-dan-hiu-koboy/ diakses pada 17 April 2015 pukul 11:35.

78 Kharina Trianada, "Dampak Kepunahan Hiu bagi Keseimbangan Ekosistem Laut," Berita Satu, 9 Juni 2013, Sumber: http:// www.beritasatu.com/iptek/118539-dampak-kepunahan-hiu-bagikeseimbangan-ekosistem-laut.html 19 April 2015.

79 Berdasarkan penelitian ilmuwan, hiu harimau di Hawaii mempunyai dampak positif bagi kesehatan padang lamun. Hiu ini merupakan pemangsa kura-kura, ketika hiu tidak ada, kura-kura tersebut menghabisi seluruh nutrisi 
dampak kerusakan yang dapat ditimbulkan dalam kasus tersebut, pengambilan udang dan lobster yang ternyata masuk zona TNUK tidak menyebabkan dampak masif bagi ekosistem laut, bahkan dapat dikatakan tidak merusak kawasan konservasi tersebut.

Dampak lingkungan perlu menjadi perhatian penegak hukum dalam rangka melakukan perlindungan lingkungan dengan perspektif CBDR untuk mencapai keadilan distributif. Dalam konteks lingkungan hidup, keadilan distributif ini terkait dengan persamaan perlakuan (equal treatment) atas beban dan dampak lingkungan yang dihasilkan dari kegiatan yang membahayakan lingkungan. Dengan demikian, keadilan distributif memberikan perhatian pada dampak lingkungan yang terdistribusi secara tidak adil, dimana kelompok masyarakat miskin, perempuan, dan ras tertentu sering kali merupakan kelompok yang paling merasakan dampak lingkungan tersebut. ${ }^{80}$

\section{Penutup}

Pada penegakan hukum kasus nelayan TNUK dan MV Hai Fa, penegak hukum belum terlihat menggunakan perspektif keadilan intra generasi. Dalam kasus nelayan TNUK, penegak hukum seperti polisi dan jaksa hanya menerapkan ketentuan hukum tanpa mempertimbangkan aspek lainnya. Hal ini terbukti dari pilihan penegakan hukum yang mengenyampingkan diskresi mulai dari proses penyidikan sampai penuntutan, yang memberikan perlakuan sama tanpa melihat kesenjangan struktural tiga orang nelayan TNUK. Dalam kasus MV Hai Fa, jaksa tidak menuntut pasal-pasal yang sebenarnya dapat ditujukan kepada pelaku dan menggunakan jenis dakwaan yang cukup lemah yaitu dakwaan alternatif. Terlebih, hakim juga memutus perkara sebatas apa yang dituntut oleh jaksa.

Penegakan hukum lingkungan dalam masalah struktural tidak bisa hanya berlandaskan prinsip legisme ${ }^{81}$ hukum semata. Ada aspekaspek non-yuridis lain yang perlu dipertimbangkan seperti ketersediaan

terbaik yang membuat habitat ini hancur. Keberadaan hiu membuat kura-kura di daerah tersebut berpencar untuk makan di berbagai wilayah. "Sharks Role in The Ocean," Sumber: http://www.sharksavers.org/en/education/the-value-ofsharks/sharks-role-in-the-ocean/ 19 April 2015.

${ }^{80}$ Andri Wibisana, Op. Cit., hal. 4.

81 Soedikno Merto Koesomo, loc.cit., hal. 76. 
sarana yang dipunyai masyarakat untuk dapat mematuhi suatu aturan hukum. Penegak hukum dalam kasus struktural terkait lingkungan hidup tidak dapat menegasikan adanya keterbatasan akses masyarakat kecil seperti nelayan terhadap SDA karena tidak terwujudkannya keadilan SDA. Pernyataan tersebut bukan pembenaran bagi siapa saja untuk merusak lingkungan di kawasan konservasi atau melanggar peraturan tetapi hanya sebagai alat bantu untuk melihat hubungan sebab-akibat dari suatu masalah. Kondisi tersebut dapat tergali apabila penegak hukum memiliki perpektif keadilan intra generasi.

Dalam penegakan hukum, untuk menghindari hukum yang tajam ke bawah dan tumpul ke atas, perbedaan tanggung jawab atas akibat yang ditimbulkan perusak lingkungan patut diaplikasikan untuk menindak pelaku-pelaku besar, terutama di kawasan laut. Penindakan tidak hanya ditujukan pada pelaku fisik tetapi juga pelaku fungsional dalam kejahatan lingkungan skala besar, dalam hal ini kejahatan yang melibatkan korporasi. Penegak hukum perlu membedakan perlakuan penanganan kasus struktural dan kasus besar. Tindakan afirmatif bukan hanya ditujukan kepada mereka yang berada di dalam kasus struktural, tetapi juga bagi mereka yang berada di kasus besar supaya pelaku ditindak tegas berdasar kerusakan lingkungan yang ditimbulkan. Oleh karena itu, asas kesamaan dalam penegakan hukum di dua kasus ini tidak bisa ditelan bulat. Dengan perspektif pembangunan berkelanjutan melalui elemen keadilan intra generasi, penegakan hukum lingkungan harus berpihak dengan alat perlakuan khusus atau tindakan afirmatif.

Terakhir, sebelum sampai pada tahapan penegakan hukum, sebaiknya pembuat kebijakan dapat membuat kebijakan konsensus dengan masyakat, dimana dalam pembentukannya masyarakat diberi ruang untuk berkomunikasi dan menentukan pendapat yang menentukan hasil dari suatu kebijakan melalui konsepsi komunikasi Habernas. Saat komunikasi dan pelibatan sudah berjalan, keadilan prosedural mulai tercapai. Keadilan prosedural merupakan sarana utama bagi tercapainya keadilan sosial dalam perlindungan lingkungan, sehingga perlindungan tidak memiskinkan, tetapi menyejahterakan. Sekali lagi, semua itu memerlukan tindakan khusus dalam bentuk penyediaan sarana bagi para nelayan.

\section{Daftar Pustaka}

Adler, Freda. Criminology. New York: McGraw-Hill, 2001. 
Asshiddiqie, Prof.Dr. Jimly dan M. Ali Sa'at. Teori Hans Kelsen. Jakarta: Konpress, 2012.

Binawan, Al. Andang L. Jalan Terjal Ekokrasi dalam Jurnal Hukum Lingkungan Volume-1 ICEL. Jakarta: Januari, 2014.

Bonger, W.A. Pengantar Tetang Kriminologi. cet. 6. Jakarta: PT. Pembangunan Ghalia Indonesia, 1982.

Danardo, Donny. Mepertimbangkan Brian Z. Tamanaha: Sosio-Legal Positivis, Anti- Esensialisme, dan Pragmatisme dalam Sosiologi Hukum dalam Perubahan. Jakarta: $\quad$ Yayasan Obor Indonesia, 2009.

Gosita, Arif. Masalah Korban Kejahatan. Jakarta: Akademika Presindo, 1993.

Hamzah, Andi. Hukum Acara Pidana Indonesia. Jakarta: Sinar Grafika, 2010.

Harahap, M. Yahya. Pembahasan Permasalahan dan Penerapan KUHAP: Pemeriksaan Sidang Pengadilan, Banding, Kasasi, dan Peninjuan Kembali. Edisi $2 . \quad$ cet. 3. Jakarta: Sinar Grafika, 2002.

Indrati, Maria Farida. Ilmu Perundang-Undangan 2. Jakarta: Kanisius, 2007.

Kusomo, Sudikno. M. Mengenal Hukum Suatu Pengantar. Yogyakarta : Liberti, 2007.

Malaka, Tan. Madilog (Materialisme, Dialektika, dan Logika). Jakarta: LPPM Tan Malaka, 2008.Santoso, Topo dan Eva Achjani Zulfa. Kriminologi. Jakarta: Raja

Sembiring, Raynaldo. Anotasi Undang-Undang Nomor 32 Tahun 2009 Tentang Perlindungan dan Pengelolaan Lingkungan Hidup. Jakar

Sjahdeini, Sutan Rehmi. Pertanggungjawaban Pidana Korporasi. Jakarta: Grafiti Press, 2006.

Sulistyowati Irianto, Menuju Pembangunan Hukum Pro Keadilan Rakyat dalam Sosiologi Hukum dalam Pembangunan. Jakarta: Yayasan Obor Indonesia, 2009.

Tim Penulis ICEL. Sertifikasi Hakim Lingkungan Hidup. Jakarta: ICEL, 2014.

Wibisana, Andri G. Elemen-elemen Pembangungan Berkelanjutan: Keadilan Intra dan Antar Generasi

“Moratorium Ekspor Hiu Martil dan Hiu Koboi." Maritime Magazine. Sumber: http://maritimemagz.com/moratorium-ekspor-hiu-martil-danhiu-koboy 
"Sharks Role in the Ocean." Sharksavers. Sumber: http://www.sharksavers.org/en/education/the-value-of-sharks/sharks-rolein-the-ocean

"Kabareskrim: Diskresi Polisi Harus Dibatasi." Hukum Online. http:// www.hukumonline.com/berita/baca/lt5059b7d1c3d3c/ka bareskrim--diskresi-polisi-harus-dibatasi

"3 Nelayan Terancam 5 Tahun Bui Karena Dituduh Curi Kepiting." Merdeka.com. Sumber: http://www.merdeka.com/peristiwa/3-nelayanterancam-5-tahun-bui-karena-dituduh-curi-kepiting.html

“Kasus Kapal Maling Ikan Hai Fa Dituntut Ringan, Penegak Hukum Harus Lebih Jeli." Detik.com. Sumber: http://news.detik.com/read/2015/03/29/093954/2872642/10/kasus-kapalmaling-ikan-hai-fa-dituntut-ringan-penegak-hukum-harus-lebih-jeli

“Gelombang Ganas Nelayan Miskin Penangkap 4 Udang Terbebas dari Penjara." Detik.com. Sumber: http://news.detik.com/read/2015/01/29/095247/2817229/10/gelombangganas-nelayan-miskin-penangkap-4-udang-terbebas-dari-penjara

“Menteri Susi Tegaskan Kapal MV Hai Fa Ilegal." Liputan 6. Sumber: http:/ / bisnis.liputan6.com/read/2212459/menteri-susi-tegaskankapal-mv-Hai Fa-ilegal 